\title{
Histochemical Observations of Individual Skeletal Muscle Fibers in Starved Sheep
}

\author{
Atsushi Suzuki \\ Faculty of Agriculture, Tohoku University, Sendai-shi 980 \\ (Received July 28, 1972)
}

\begin{abstract}
The muscles of starved sheep were examined histochemically in order to obtain information on the effect of starvation on the five fiber types $(A, B, C, D$, and E) classified in the normal sheep.

In starvation, all the fiber types were little changed in NADH-diaphorase and mitochondrial ATPase activity and unchanged in myosin ATPase activity. The decrease in succinic dehydrogenase (SDH) and phosphorylase activity and in glycogen content was more frequently observed in the $B$ fibers, frequently in the A fibers and less frequently in the $\mathrm{C}$ fibers. The $\mathrm{D}$ fibers were hardly changed in the enzyme activities and glycogen content. The $\mathrm{E}$ fibers decreased slightly in phospohrylase activity and glycogen content, but not in SDH activity. The disappearance of glycogen was followed by the decrease and disappearance of phosphorylase activity in individual fibers.

The changes in the fiber population, in the A and B fibers, were observed in certain kinds of the muscles. Reduction in fiber size was generally marked in the $B$ and $E$ fibers, moderate in the $\mathrm{C}$ fibers, and slight in the $\mathrm{A}$ fibers. The $\mathrm{D}$ fibers were unchanged in size. These results indicated that the white fiber ( $B$ fiber) was affected more greatly by starvation than the red fiber $(A, C, D$, and $E)$.
\end{abstract}

In the sheep, skeletal muscle fibers were histochemically classified into five types ( $A, B$, $C, D$, and $E$ ) in connection with the relative activity of several enzymes ${ }^{-3}$ ). The $A, B$ and $\mathrm{C}$ fibers were present in all the muscles used except the $M$. masseter, while the $\mathrm{D}$ fibers were found only in certain kinds of the muscles observed. The $M$. masseter comprised only the E fibers.

Little is known about the effect of low level of nutritional state on the enzyme-histochemical properties of the fiber types, though the histochemical changes in the affected muscle fibers have been investigated in tenotomy and denervation ${ }^{4-6)}$, and in dystrophic animal7 and human muscle disease ${ }^{8}$.

It was previously reported that there were smaller and larger types of fibers in certain kinds of sheep muscles, and that in starvation the larger type was hardly changed in fiber size and glycogen content in contrast to the smaller type that was greatly affected ${ }^{9}$. The present study was designed in order to obtain information on the effect of starvation on the five fiber types.

\section{Materials and Methods}

Four adult female sheep weighing more than $40 \mathrm{~kg}$ were used. No feed was given to them from the start of the experiment to the time of slaughter, though water was freely available. 


\section{Histochemistry of Muscle in Starved Sheep}

The animals were housed separately in pens without any bedding for 32 to 38 days. Each sheep was weighed at the beginning of the experiment and at slaughter. After slaughter, samples were immediately excised from the belly of the following muscles; $M$. serratus ventralis, $M$. supraspinatus, $M$. infraspinatus, $M$. longissimus thoracis ( $M$. longissimus dorsi), $M$. semiten. dinosus, and $M$. masseter. SDH*), NADH-diaphorase, ATPase at $\mathrm{pH} 9.4$ and at $\mathrm{pH} 7.2$, phosphorylase, and glycogen were demonstrated histochemically by the same methods employed in the previous paper'1). The percentage of fiber types in five muscles and the fiber diameter of each type were determined in the same manner as in the previous paper'1.

Three adult female sheep (Nos. I, II and III) were fed ad libitum under the same circumstances as the starved animals, and served as the control. The results of the investigations on individual muscle fibers in these animals were previously reported ${ }^{1-8}$.

\section{Results}

Loss of body weight at slaughter in the individuals varied from 26.3 to $41.5 \%$ (Table 1 ).

1. SDH. The majority of fibers decreased in SDH activity during starvation (Figs. 1, 2). The changes in the enzyme activity were grossly indicated by the decrease in the number and size of diformazan granules as compared with the normal fibers ${ }^{1-31}$. Generally, the SDH activity decreased moderately in the A fibers, little to moderately in the $B$ fibers and less in the $\mathrm{C}$ fibers. It was hardly changed in the $\mathrm{D}$ fibers, and unchanged in the. $\mathrm{E}$ fibers (Figs. $7,8)$.

2. NADH-diaphorase. The distribution pattern of diformazan granules in NADH-diaphorase reaction was similar to that in SDH reaction. The decrease in the activity of the former was much less than that of the latter. The diformazan granules were distinctly visible in NADH-diaphorase reaction (Figs. 3, 9).

3. ATPase. The reaction for myosin ATPase ( $\mathrm{pH} \mathrm{9.4)} \mathrm{was} \mathrm{unchanged} \mathrm{in} \mathrm{all} \mathrm{the} \mathrm{fibers.}$ In atrophic fibers, light and dark fibers in myosin ATPase reaction were clearly distinguishable as observed in the normal fibers (Figs. 4,10). This made it possible to distinguish four fiber types ( $A, B, C$, and $D$ ) in connection with the relative activity of SDH and NADH-diaphorase.

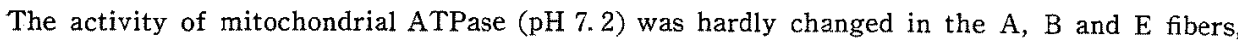
while it increased slightly in some of the $C$ and $D$ fibers.

4. Phosphorylase. The majority of fibers reacted either negatively or much weakly for phosphorylase. The decrease and disappearance of this activity were more frequently seen in the $B$ fibers than in the $A$ fibers, and less frequently in the $C$ fibers (Figs. 5, 11). The

Table 1. Loss of body weight in starvation

\begin{tabular}{lcccc}
\hline \multicolumn{1}{c}{ No. of individuals } & 1 & 2 & 3 & 4 \\
\hline Starvation period, days & 32 & 33 & 38 & 38 \\
Initial weight, kg & 40.0 & 49.9 & 50.2 & 70.0 \\
Final weight, kg & 23.4 & 30.0 & 36.1 & 51.1 \\
Body weight loss, \% & 41.5 & 39.7 & 27.8 & 26.3 \\
\hline
\end{tabular}

*) The following abbrevations will be used in this paper: SDH, succinic dehydrogenase; NADH, dihydronicotinamide adenine dinucleotide; ATPase, adenosine triphosphatase. 
majority of the D fibers were unchanged in the activity, but some of the $D$ fibers increased slightly. Most of the $\mathrm{E}$ fibers decreased slightly in the activity. The decrease and disappearance of phosphorylase activity were not directly related to the reduction in fiber size.

5. Glycogen. The decrease and disappearance of glycogen were observed more frequently in the $B$ fibers, frequently in the $A$ fibers and less frequently in the $C$ fibers (Figs. 6, 12). The majority of the $\mathrm{D}$ fibers were unchanged in glycogen content, but some of the $\mathrm{D}$ fibers appeared to increase slightly in the content (Fig. 12). The E fibers without glycogen became larger in number. The observation in serial cross sections showed that the fibers reacting positively for phosphorylase were stained negatively or positively with PAS reaction, whereas the fibers reacting negatively for phosphorylase contained no glycogen. This indicated that the disappearance of glycogen was followed by the decrease and disappearance of the phosphorylase activity in the individual fibers.

6. Changes in fiber population. As compared with the distribution of four fiber types in the normal muscles ${ }^{1-3}$, the $\mathrm{A}$ fibers in the $M$. semitendinosus and the $\mathrm{B}$ fibers in the $M$. longissimus thoracis and $M$. infraspinatus tended to increase in percentage (Table 2). In other muscles the percentage of the A, B and C fibers appeared to be unchanged. The D fibers were unchanged in fiber population.

7. Changes in fiber diameter. The $A, B$ and $C$ fibers tended to reduce in size in the $M$. semitendinosus in comparison with the average diameter of the normal fibers (Table 2,3 ). The $\mathrm{B}$ fibers of other muscles and the $\mathrm{E}$ fibers reduced obviously in size. The $\mathrm{C}$ fibers reduced in size in the $M$. serratus ventralis and $M$. supraspinatus, but not in other muscles. The $A$ fibers showed generally a tendency to reduce in size in all the muscles used, while the D fibers were unchanged in size.

Table 2. Changes in fiber population and fiber diameter of five fiber types in starvation

\begin{tabular}{|c|c|c|c|c|c|}
\hline & & \multicolumn{2}{|c|}{ Fiber population (\%) } & \multicolumn{2}{|c|}{ Fiber diameter $(\mu)$} \\
\hline & & Control* & Starvation $* *$ & Control* & Starvation** \\
\hline$M$. semitendinosus & $\begin{array}{l}A \\
B \\
C\end{array}$ & $\begin{array}{l}32.4 \\
56.3 \\
11.3\end{array}$ & $\begin{array}{r}40.6 \\
50.1 \\
9.3\end{array}$ & $\begin{array}{l}33.4 \\
40.9 \\
40.2\end{array}$ & $\begin{array}{l}34.7 \\
35.8 \\
36.1\end{array}$ \\
\hline$M$. longissimus thoracis & $\begin{array}{l}\mathrm{A} \\
\mathrm{B} \\
\mathrm{C}\end{array}$ & $\begin{array}{l}45.3 \\
42.9 \\
11.8\end{array}$ & $\begin{array}{r}35.9 \\
56.6 \\
7.5\end{array}$ & $\begin{array}{l}29.0 \\
44.2 \\
42.3\end{array}$ & $\begin{array}{l}27.1 \\
28.8^{a)} \\
33.6\end{array}$ \\
\hline$M$. serratus ventralis & $\begin{array}{l}\mathrm{A} \\
\mathrm{B} \\
\mathrm{C} \\
\mathrm{D}\end{array}$ & $\begin{array}{l}27.5 \\
36.7 \\
20.0 \\
15.8\end{array}$ & $\begin{array}{l}29.4 \\
36.5 \\
23.1 \\
11.0\end{array}$ & $\begin{array}{l}37.1 \\
40.3 \\
43.4 \\
56.1\end{array}$ & $\begin{array}{l}32.3^{\prime} \\
33.1^{\text {by }} \\
37.4^{\text {b) }} \\
67.2\end{array}$ \\
\hline M. supraspinptus & $\begin{array}{l}A \\
B \\
C \\
D\end{array}$ & $\begin{array}{r}35.7 \\
35.2 \\
22.0 \\
7.1\end{array}$ & $\begin{array}{r}41.3 \\
33.2 \\
17.9 \\
7.6\end{array}$ & $\begin{array}{l}37.4 \\
41.4 \\
46.1 \\
68.4\end{array}$ & $\begin{array}{l}33.0^{b} \\
31.9^{b 1} \\
38.5^{b 1} \\
69.4\end{array}$ \\
\hline$M$. infraspinatus & $\begin{array}{l}\mathrm{A} \\
\mathrm{B} \\
\mathrm{C} \\
\mathrm{D}\end{array}$ & $\begin{array}{r}35.9 \\
36.7 \\
20.4 \\
7.0\end{array}$ & $\begin{array}{r}32.1 \\
45.1 \\
14.3 \\
8.5\end{array}$ & $\begin{array}{l}45.0 \\
46.5 \\
51.6 \\
64.2\end{array}$ & $\begin{array}{l}39.6 \\
37.2^{\text {a) }} \\
48.3 \\
64.7\end{array}$ \\
\hline M. masseter & $\mathrm{E}$ & - & - & 49.1 & $39.1^{\text {a) }}$ \\
\hline
\end{tabular}

* a mean of three animaIs (Nos. I, II and III) described in the previous papers. ${ }^{1-8}$ )

** a mean of four animals.

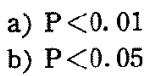


Histochemistry of Muscle in Starved Sheep

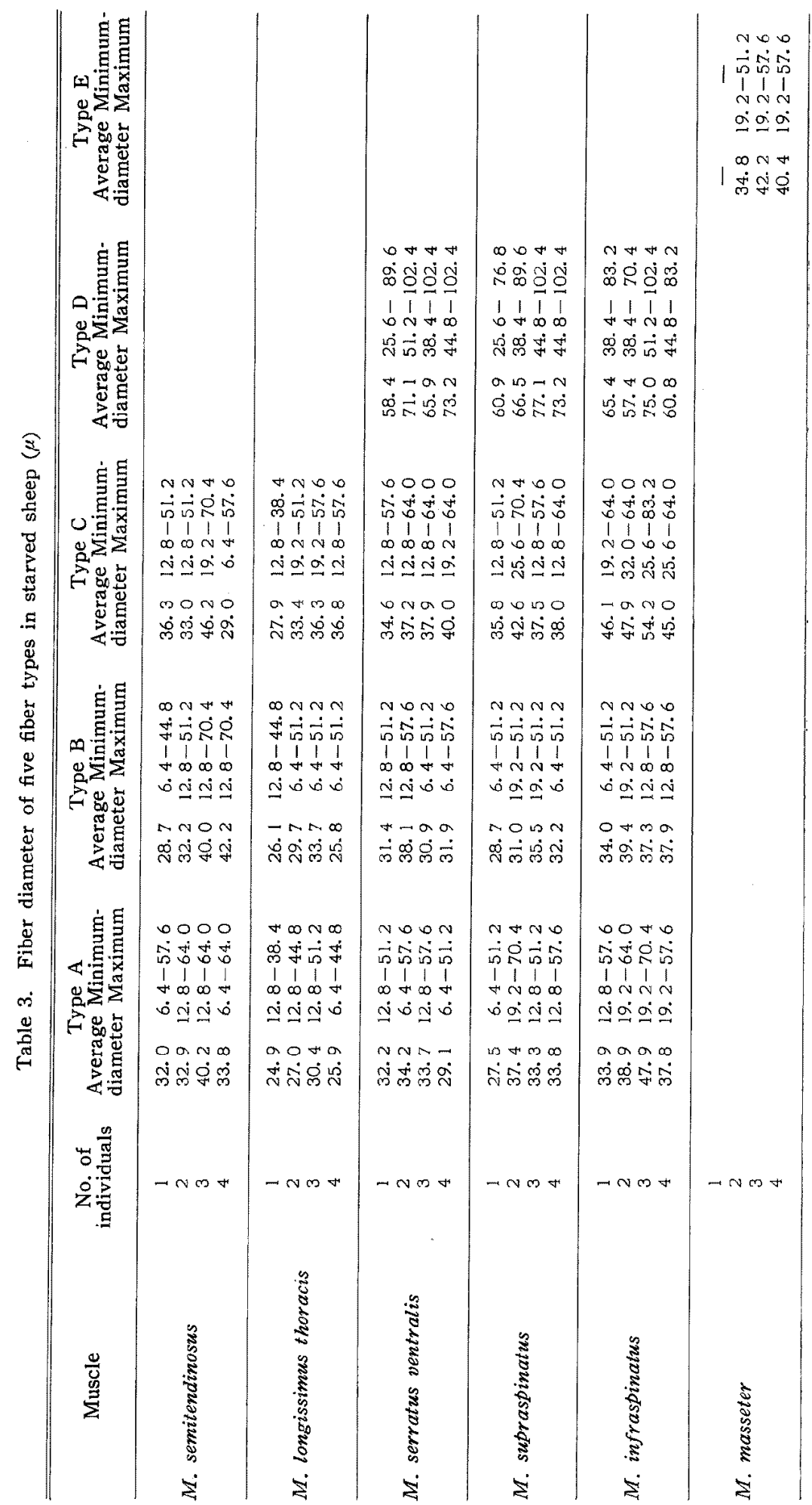




\section{Discussion}

In this study, the sheep died sometimes after the 40th day of starvation, or when live body weight decreased rapidly. The animals were, therefore, slaughtered before the 40 th day of starvation.

The five fiber types previously classified in the normal sheep were distinguished in the starved sheep. The increase in the number of the $B$ fiber, accompanied by the decrease in that of the A fiber, was observed in certain kinds of the muscles in starvation. Similar findings were reported in the $M$. trapezius of the fasted pig ${ }^{10}$. The decrease in the number of the A fiber may possibly be caused by simple reduction in the number of mitochondria in the A fibers. It remains obscure whether the intrinsic properties of the A fibers were transformed into those of the $B$ fibers. No alteration in the percentage of the $C, D$ and $E$ fibers was noted. This indicated that they were not transformed into other types during starvation.

During starvation, the $A$ and $B$ fibers showed the decrease in SDH and phosphorylase activity and glycogen centent. The decrease was much more marked in the $B$ fibers than in the $A$ fibers, less in the $C$ fibers and least in the $D$ and $E$ fibers. On the other hand, the $B$ fibers reduced more markedly in size than other fiber types did. These indicated that the $B$ fibers, equivalent to white fiber, were affected more greatly than other types, equivalent to red fiber. This is in agreement with the results that the white fiber was more rapidly atrophied than the red fibers in denervated cat, mouse and guinea pigi-6).

Some of the A fibers showing the decrease in SDH and NADH-diaphorase activity reduced little in size, while some of the $C$ fibers with little alteration in the enzyme activity reduced in size. This showed that mitochondria reduced in number with a loss of contractile materials ${ }^{11,12}$.

The $\mathrm{D}$ fibers were generally aunchanged in the enzyme activity and remained as large in size as the normal ones. This demonstrates that the $D$ fibers are identical to the larger type of fiber that showed resistance to the atrophy ${ }^{9}$. Similarly, it was presumed that the E fibers showed a resistance to the atrophy because of the unchanged enzyme activity, although they reduced in size.

The myosin ATPase activity was unchanged in each fiber type in starvation. The unchanged myosin ATPase activity in atrophic fibers was observed in Marcaine-treated muscles ${ }^{13 !}$, and in denervative and tenotomized muscles ${ }^{5,6}$. Although it was tempting to speculate that the loss of contractile materials caused a change of dark fiber to light fiber, the myosin ATPase activity was not related to the atrophy of the individual fibers. The present study supported the hypothesis of ENGEL et al. ${ }^{5}$, who suggested that myosin ATPase reaction represents the original histochemical type of the fiber.

It has previously reported that the glycogen content in the fibers decreased strikingly during starvation'. In this study, it was strongly suggested that the decrease and disappearance of phosphorylase were caused by the disappearance of glycogen in individual fibers. Similar phenomena have been reported by KUGELBERG and EdsTrom ${ }^{14}$, who suggested that the histochemical methods demonstratc active phosphorylase rather than total phosphorylase. It has been demonstrated that glycogen is involved in the activation of muscle phosphorylase $\mathrm{a}^{15)}$. The recent biochemical information indicates that the reaction cascade for the activation of muscle phosphorylase is very intricate ${ }^{16}$. From these points of view, it may be assumed 
that the changes in phosphorylase activity in starvation is due to decrease and disappearance in active form rather than total phosphorylase.

The $\mathrm{D}$ fiber ${ }^{2)}$ or the larger type of Suzuk19) differed intrinsically from the abnormal giant fiber observed in pig muscles ${ }^{17}$ ). The present observations suggested that the $D$ fibers of the starved sheep remained functionally as nearly active as the ones of the normal animals. However, this fiber as well as other fiber types showed occasionally a disorder in distribution pattern of diformazan granules. The details of the alteration will be reported later.

The author wishes to thank Prof., Dr. H. TAmate for many helpful discussions and sug. gestions during this work. Thanks are also due to Prof., Dr. K. TAMASAKI in the Department of Animal Husbandry, Faculty of Agriculture, Ibaraki University for his advice and encourage. ment during this work.

\section{References}

1) SuzukI, A., Jap J Zootech Sci 42: 39-54. 1971.

2) Suzuki, A., Jap J Zootech Sci 42: 463-473. 1971.

3) Suzuki, A., Jap J Zootech Sci 43: 161-166. 1972.

4) Bajusz, E., Science 145: 938-939. 1964.

5) Enged, W.K., M.H. Brooke, and P.G. Nelson, Ann NY Acad Sci 138 (1): 160-185. 1965.

6) Karpati, G., and W.K. Engel, Amer J Anat 122: 145-156. 1968.

7) Fennell, R.A., and W.T. West, J Histochem Cytochem 11: 374-382. 1963.

8) Dubowitz, V., and A.G.E. Pearse, J Path Bact 81: 365-378. 1961.

9) Suzuki, A., Tohoku J Agr Res 16: 117-139. 1965.

10) Moody, W.G., R.G. Kauffman, and R.G. Cassens, J Anim Sci 28: 746-749. 1969.

11) Suzuki, A., Sci Rep Fac Agr Ibaraki Univ 17: 13-30. 1969.

12) Peleegrino, C., and C. Franzini, J Cell Biol 17: 327-349. 1963.

13) Libelius, R., B. Sonesson, B.A. Stamenovic, and S. Thesleff, J Anat 106: 297-309. 1970.

14) Kugelberg, E., and L. Edström, J Neurol Neurosurg Psychiat 31: 415-423. 1968.

15) Metzger, B.E., E. Helmreich, and L. Glaser, Proc Nat Acad Sci USA 57: 994-1001. 1967.

16) Helmreich, E., Metabolic Regulation and Enzyme Action 131-148. Acad. Press. London. 1969.

17) Cassens, R.G., C.C. Cooper, and E.J. Briskey, Acta Neuropath 12: 300-304. 1969. 


\title{
飢餓めん羊に少ける骨格筋線維の組織化学的研究
}

\author{
鈴嵉 \\ 東北大学農学部，仙台市 980
}

ஐえ羊の 5 種類の骨格筋線維 (A, B , C , D, E 型) 飞及

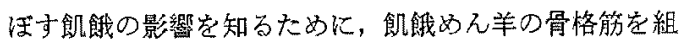
織化学的に調べた。

飢餓において，NADH ジフホラーゼとミトコンドリ フのATP アーゼの活性の変化は，すべての筋線維型で 少く, ミオシンATP フーゼ活性の変化はなかった。 $\mathrm{SDH}$ とホスホリラーゼの活性狲よびグリコーグン量の減 少は, B 型線維で多く観察され, 次にA 型線維で, C 型 線維ては少なかった，D型線維では，これらの醉素活性 とグリコーダン量はほとんど変化しなかった． E型線維
では，ホスホリラーゼ活性とグリコーゲン量はわずかに 減少するが, SDH 活性の变化はなかっった。

各筋線維型の分布状態の変化は, $\mathrm{A}$ 型と B 型線維で, ある種の笳肉に見られた，筋線踓の萎縮は，B型と $\mathrm{E}$ 型 線維で著しく，C型線維では中程度，A型線維ではわず かであった． D型線維は萎縮していなかったこてれらの 結果は, 白筋線維 (B型) が赤筋線維 (A, C, D, E 型) よりる飢餓による影響を著しく受けることを示してい ๖. 


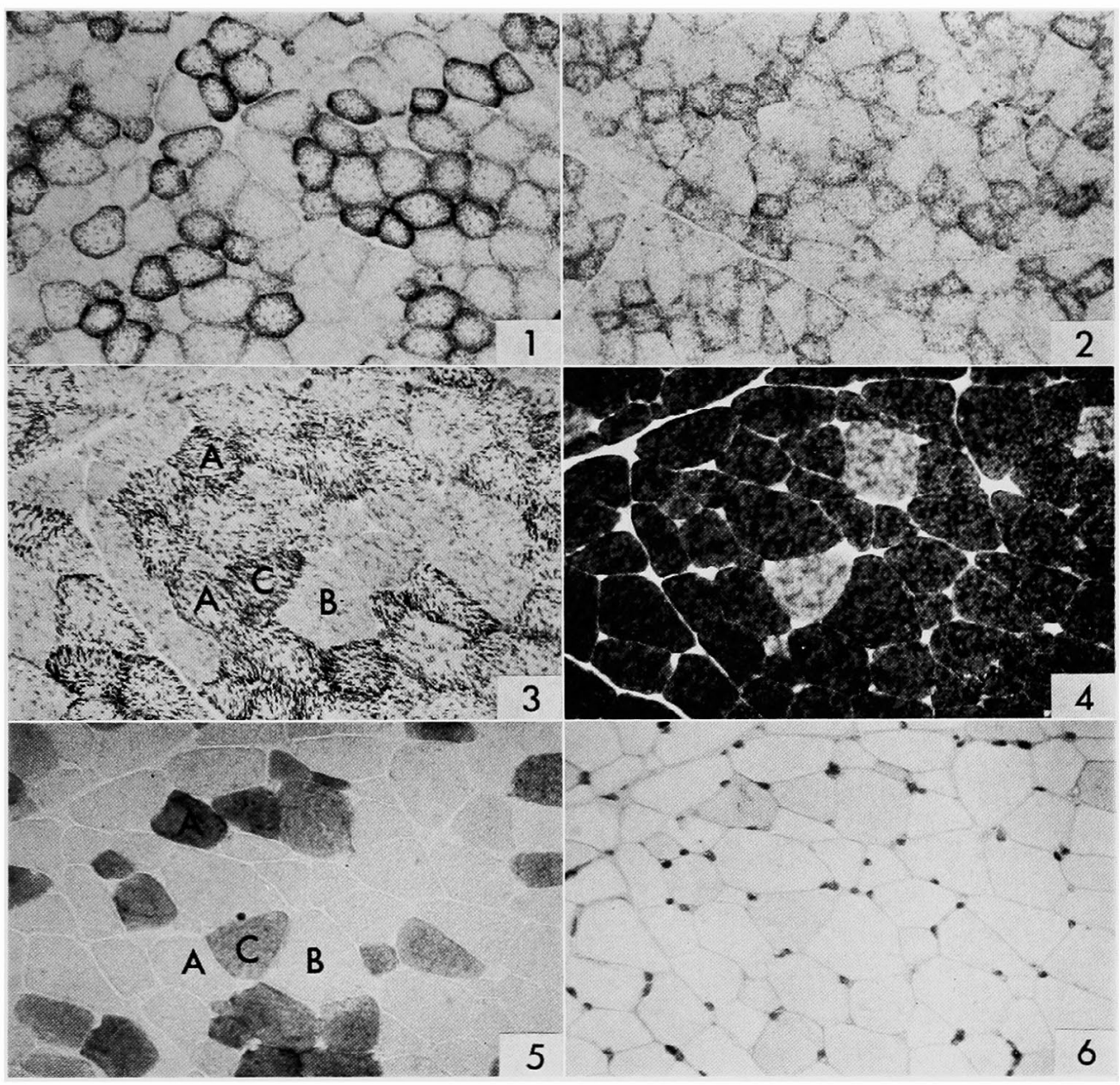

Figs. 1 and 2: The M. semitendinosus. SDH. $\times$ 133. Fig. 1. The control animal. Fig. 2. The starved animal.

Figs. 2 to 6: The $M$. semitendinosus of the starved animal. The same fields of serial cross sections. $\times 250$. A, B and $\mathrm{C}$ indicate the type $\mathrm{A}, \mathrm{B}$ and $\mathrm{C}$ fibers, respectively. Fig. 3 . NADH-diaphorase. Fig. 4. Myosin ATPase. Fig. 5. Phosphorylase. The B fibers and some of the A fibers react negatively for phosphorylase. Fig. 6. PAS and hematoxylin stain. Most of the fibers contain no glycogen. 


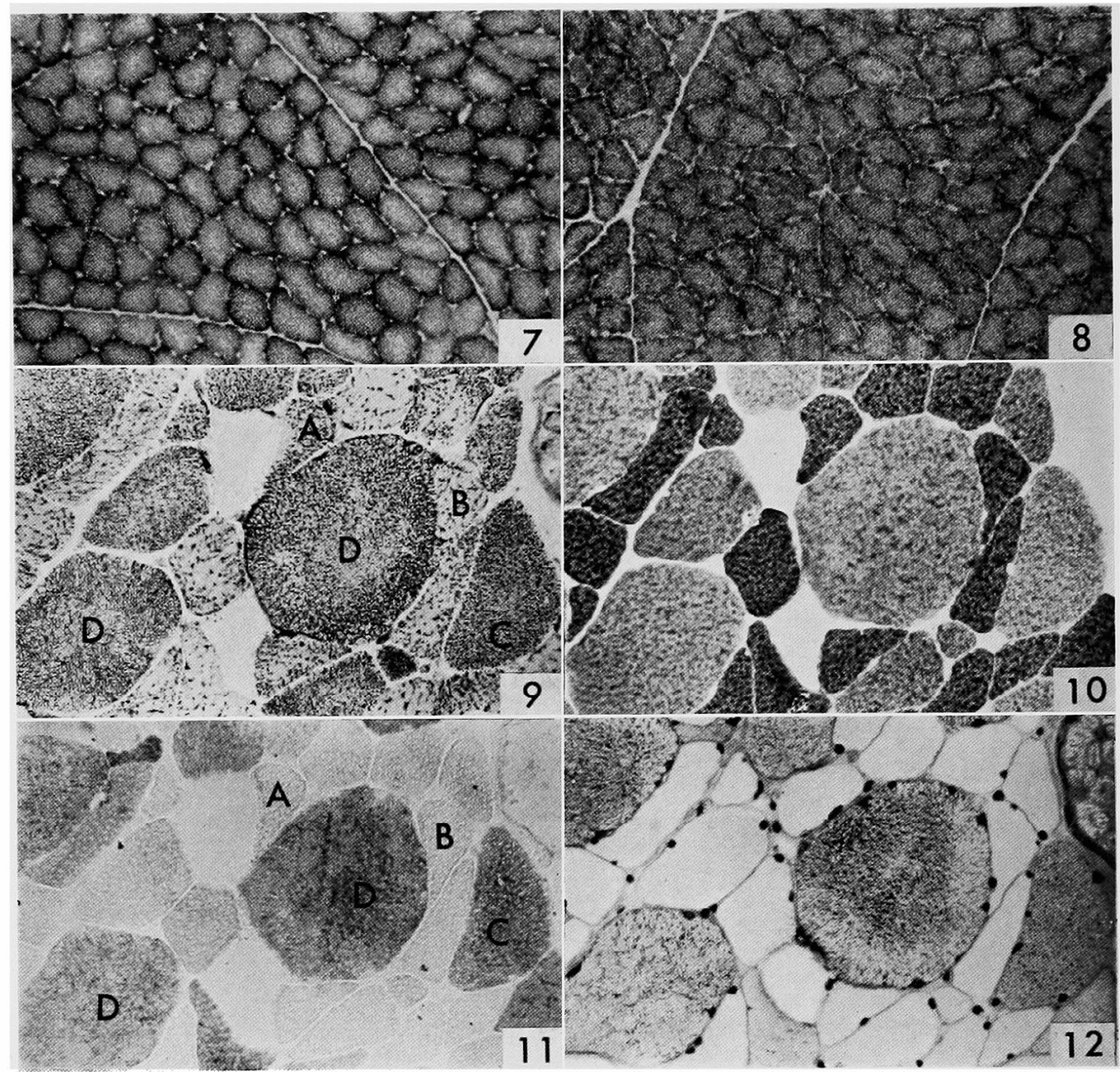

Figs. 7 and 8: The M. masseter. SDH. $\times 133$. Fig. 7. The control animal. Fig. 8 . The starved animal.

Figs. 9 to 12: The $M$. serratus ventralis of the starved animal. The same fields of serial cross sections. $\times 250$. A, B, C, and D indicate the type A, B, C, and D fibers, respectively. Fig. 9. NADH-diaphorase. Fig. 10. Myosin ATPase. Fig. 11. Phosphorylase. Fig. 12. PAS and hematoxylin stain. The D fibers and some of the $\mathrm{C}$ fibers react positively for phosphorylase and glycogen. 